\title{
Enchantment - Disenchantment-Re-Enchantment: Postdigital Relationships between Science, Philosophy, and Religion
}

\author{
John Reader, et al. [full author details at the end of the article]
}

Published online: 6 July 2020

(C) Springer Nature Switzerland AG 2020

\begin{abstract}
This collectively written article explores postdigital relationships between science, philosophy, and religion within the continuum of enchantment, disenchantment, and re-enchantment. Contributions are broadly classified within four sections related to academic fields of philosophy, theology, critical theory, and postdigital studies. The article reveals complex and nuanced relationships between various disciplinary perspectives, religions, and political positions, and points towards lot of commonalities between their views to the enchantment, disenchantment, re-enchantment continuum. Some commonly discussed questions include: Where do the mythical, mystical and spiritual end and the rational, objective and empirical begin? How do we find our bearings in the midst of this complexity and where do we search for resources that are trustworthy and reliable? While the article inevitably offers more questions than answers, a common thread between all contributions is the need for an open postdigital dialogue conducted in the spirit of mutual understanding and respect. It is with this conclusion that the article offers a possible route for further development of such dialogue in the future.
\end{abstract}

Keywords Religion - Science · Philosophy · Postdigital · Dialogue · Collective Research · Enchantment $\cdot$ Disenchantment $\cdot$ Re-Enchantment $\cdot$ Christianity $\cdot$ Islam

\section{Introduction (John Reader and Petar Jandrić)}

For the biggest part of human history, science and philosophy have always been dialectically intertwined with religion. Looking at development of Western thought, Steve Fuller suggests that 'that we wouldn't have gone down the path of modern scientific inquiry at all without the predominance of the world-view associated with the Abrahamic faiths' (in Fuller and Jandrić 2019: 203); similar connections can be found in various Eastern traditions (Peters 2019). Yet, contemporary science and philosophy are strongly methodologically, practically, and politically separated from religion. While it is only reasonable to protect modern-day Galileos from various 'inquisitions', and while it would be meaningless to try and understand the Book of Genesis using scientific methods such as radiocarbon dating, our current divisions between science 
and religion arrive at a high cost. Choosing to ignore millennia of shared history between science, philosophy, and religion, we do not merely 'protect' these grand systems of thought from each other. Along the way, unfortunately, we also lose their historicity, their shared wisdom, and opportunities for productive collaboration.

Religion works on the basis of an enchanted world (spirits; myths; magical or providential events; external interventions; etc.). Science then disenchants this world through the expulsion or denial of these elements of enchantment, and replacing them with objectivity (logic; reason; autonomy; etc.). In our 'hard to define; messy; unpredictable; digital and analog; technological and non-technological; biological and informational' postdigital reality (Jandrić et al. 2018: 895), philosophies such as New Materialism can now enter the fray as vehicles of re-enchantment. Each of these statements could be contested and/or developed in creative ways as being too simplistic. However, one of the key challenges of the postdigital era is to develop new ways of reaching beyond traditional disciplinary divisions; discern and construct new (collective) subjectivities to which religion, science, and philosophy might contribute. To address this challenge, John Reader and Petar Jandrić reached out to people of various religious denominations (including atheists and agnostics) with the following question:

What can we learn from the enchantment - disenchantment - re-enchantment spectrum about a new or renewed relationship between religion, science and philosophy in the postdigital context?

We received 21 responses, which arrive from a wide spectrum of disciplinary perspectives, religions, and political positions. The first section, 'Spirit of Philosophy, Philosophy of Spirit', collects responses which can roughly be classified into the academic field of philosophy. The second section, 'Material Proof: Between Blessing and Burden', roughly belongs to theology and presents responses from various Islamic and Christian denominations. The third section, 'Why Does It (Not) Feel Empowering?', collates contributions from wide variety of feminist, postcolonialist, and other perspectives, broadly understood as critical theory. The last section, 'Postdigital Enchantments and Their Enemies', focuses to pressing questions of our today's postdigital condition in broad areas from data and algorithms to the arts.

In our messy and unpredictable postdigital reality, borders between traditional academic disciplines are fluid. Questions and conclusions freely circulate amongst replies and sections, without much regard for academic conventions, joined in a common plea to transcend restrictions of our current systems of knowledge creation and dissemination. This plea, in our opinion, offers a guideline for reading these little germs of very different wisdoms. They are warm, open-minded, and honest attempts at creating personal and emotional bridges between disjointed yet equally valuable religious and non-religious approaches at making sense of our common reality.

\section{Spirit of Philosophy, Philosophy of Spirit}

\section{Re-Enchantment of Science in the Epoch of Digital Reason (Michael A Peters)}

Scientific research is increasingly data-intensive and algorithmically driven. For instance, Himanen, Geurts, Foster, and Ronke (2019) explain its challenges this way: 
Data-driven science is heralded as a new paradigm in materials science. In this field, data is the new resource, and knowledge is extracted from materials datasets that are too big or complex for traditional human reasoning-typically with the intent to discover new or improved materials or materials phenomena. (Himanen et al. 2019)

Himanen et al. (2019) merely register a phenomenon that has been growing since the first computerization of science in the post-war era with the development of big data, open data, and linked data that represent large scale observational, experimental, computational, and reference data sets (OECD 2015). Indeed, in the 'epoch of digital reason', dataintensive science finds its early beginnings in the algebrification of logic, Boolean systems, and the emergence of two-value digital logics and their application to computer systems. Data-intensive science thus constitutes the 'epoch of digital reason' (Peters 2017) that while taking a new instrumental direction that encourages numerical representation of reality is also often advanced in tandem with a more open, collaborative, participatory, and citizen-science perspective especially for projects with very large data sets.

These new open and citizen-based elements open the door to multiple versions with the promising prospect of a re-enchantment of science through a return to a new civil science that emphasize public knowledge and journal systems with a breaking down of professional/amateur roles and a greater recognition that science and science communication cannot avoid questions of value that it, itself cannot resolve. This neo-Enlightenment civil perspective involves a science of greater relevance and application, attuned to epistemic democracies and applied communities of inquiry focusing of the politics of shared environments. Movements of non-foundationalist, non-deterministic, and ecological of process philosophy demonstrate the shift from the outdated mechanistic and deterministic science of the early modern era (Peters and Besley 2019). This re-enchantment of science is also consistent with a new ecological worldview that supports a greater integration with world indigenous cultures and Eastern holistic philosophies. In the West, there are otherwise disparate strands in a generalized systems approach that makes much of cybernetic advances and developments of chaos and complexity theory in mathematics, notions of quantum physics and quantum computing in intelligent technologies.

These trends and developments also represent a clearer picture of the choice between an algorithmically driven science that feeds off cannibalized personal data, the result of property theft, that characterize the sciences of surveillance capital, and an augmented civil science that is oriented to the future of humanity and the survival of the species. The former data-driven science is instrumentalist and directed towards the control and manipulation of populations; whereas the latter is constituted in the participation of epistemic communities in the formulation of scientific goals that ultimately reach out to spiritual values of community and species awareness.

\section{On Recovering Spirit in the World (Ronald Barnett)}

Can spirit be recovered in the world? Is this not a fundamental question of our time? Bernard Stiegler seems to think this it is indeed just such a fundamental question. But is it possible? If Protestantism was the spirit of capitalism, what might be-or should be- the spirit of our times? Is it already to be seen in a kind of spirit-of-STEM? Or is it emerging in a digital spirit? Or are we at the end of spirit, it being - in a certain sense- 
a spiritless age? Or just might some other kind of spirit, perhaps an eco-spirit, be sought and promoted?

In the world today, is there a more troubling — not to say troubled - concept than that of spirit? For many, it speaks variously of the occult, of the mysterious, of the nonempirical, of the ethereal, of mysticism, and of certain kinds of religiosity. Except as an object of study, it is a concept that produces a frisson of nervousness and discomfort. It smacks of the non-serious, being reached for as a last resort when other concepts run into the buffers and seem inadequate to a task in hand.

But why should this be? Far from residing in some other-worldly realm, isn't spirit of the here-and-now? Especially in organizational life and markedly so in organizations that are people centred-schools, hospitals, universities, social care settings, hospices, and the like - isn't spirit palpably and immediately present? On entering the door, on an initial exchange with the reception desk, on walking down a corridor or on entering a communal space, the elements of spirit are there - or not, as the case may be. This spirit is not exactly the world as will, of which Schopenhauer spoke: it is non-physical but it isn't aimless. And it can infuse the life of organizations, and is absolutely necessary to their survival and growth.

Challenges to spirit are manifold and emanate from different directions. The jury is out on the computerization of the world. In principle, it could quicken spirit, give it a new liveliness, and open paths to an imaginative spirit. But, in practice, it has become so dominated by malign forces that digital presences unduly impose themselves on human being with its mere analogue resources such that its spirit is swamped - to coin a phrase.

The onward march of the STEM world is another cause of the diminution of spirit. Again, it is not necessarily so, for science, technology, engineering, and mathematics are all fields potentially full of spirit (to which those such as Richard Feynman bear testimony). But, coupled with its dominance in knowledge policy, world rankings, and academic audit, an over-interest in STEM has suppressed creative spirit not only in the sciences (as Peter Murphy's work suggests) but also in that of the humanities, which have been obliged to play the games of STEM-oriented work.

The fate of spirit is not uni-linear. If it can be diminished, it can also be increased. Spirit is generous and springs from otherness, from a sense of value being inherent in the world. Spirit is, therefore, ecological, being infused by a concern with the fate of the world and a displacement of self. A task of organizations, accordingly, is precisely that of resuscitating their own spirit - where it is flagging - and a first move could be that of finding enchantment in the world, and of discerning how an organization can contribute to the well-being of the world. Without such an eco-spirit, the fate of the world must be evermore in peril.

\section{Religious Transhumanism as A Solution to An Age of Despair (Marcin Garbowski)}

Of all the recent intellectual currents where science, technology, and philosophy converge, transhumanism seems to be amongst the leading ones. And it is on the grounds of this intellectual framework, I shall describe as a meta-ideology in which we can observe as if in a lens the process of the re-enchantment of the techno-scientific discourse. Although proponents of transhumanism lure us with the vision of technological 'reality to be' and the enhanced 'post-human to be', transhumanism uncovers our anxieties as a species - such as the fear of death, feeling of evolutionary frailness 
and irrelevance in the face of the cosmos - and provides us with a deeper insight on who we are and what we lack.

In the ongoing multi-lateral crisis invoked by the Covid-19 pandemic, certain hopes but also shortcomings of the transhumanist project are clearly visible. The state of quarantine offers a convincing allegory of what I call 'the sphere of ease' in relation to what technology can provide to the human condition. It may create a sort of cocoon of relative comfort, sustaining our worldly existence, separating the earth's dwellers from the outside, from the realm, where the natural forces reign beyond the control of human intentionality. The technosphere provides us with a temporal-spatial zone of relative comfort and safety, where one can maintain one's this-worldly existence potentially for a very long time, yet even with advanced capabilities of life extension or cyborgization - not indefinitely. What would be the purpose of this confinement? How can this sphere be filled with meaning if we can last within in it for a very long time? The realm beyond the sphere, though pushed out to the outskirts of our attention (just as the reality of pathogenic microbes until just recently) shall always be there, for even if by means of digitalized consciousness we were capable of escaping the hazards of the biological world, the limitations inscribed in the laws of physics would eventually reach us.

This leads us to the mounting question about the purpose of such a technological confinement which bereft of meaning might seem like a luxurious prison. Extending worldly life simply for the sake of 'buying time' to pass by, seems to be a vacuous endeavour indeed. Transhumanism provides hints on how to expand this sphere, to make this cocoon much more comfortable, but of itself it does not give a clear answer as to what this is for. On its own transhumanism is an escape from inevitable temporal processes, but to what end? The conceptual predecessors of transhumanism-Nikolai Fyodorov with his cosmism and Pierre Teilhard de Chardin and his noosphereinscribed this pursuit into specific eschatological processes. Is it time to re-enchant the current with this spiritual touch?

It seems that only by coupling the material transcendence of the transhumanist project with supernatural transcendence and a feeling of deeper purpose and participation specific for the Abrahamic religions, one can appreciate the fruits of technological progress as well as gain the humility and deeper perspective to stop fleeing from mortality and fortuitousness, but to rather embrace it. Thanks to the perspective of the 'real world' extending beyond what is physically detectible and examinable we can replace escapism from ultimate despair with a persistent, perpetual pursuit of virtue aimed at achieving the 'greater good'.

\section{On Philosophical Foundations of Modern Technology (Veronika Lipinska)}

Contemporary science and philosophy are strongly methodologically, practically, and politically separated from religion. This is especially true at the institutional level, where state-funded universities and research institutes in the West pursue a science agenda under the rubric of 'ethics' rather than 'religion'. However, given that most modern commercial technology is developed away from state-controlled science labs and in the open market, it is unsurprisingly informed by private investors' beliefs, not least those of Silicon Valley entrepreneurs. This is where the science and technology become 'disenchanted' in somewhat specific sense, 
reflecting the ignorance of seemingly agnostic scientists and entrepreneurs of their own cultural rootedness in the Abrahamic, usually Christian tradition. It influences their judgement just as much as the internal rate of return in making decisions that drive the future of technology.

Whilst the giants of technology such as Elon Musk publicly claim philosophical alliances with the likes of avowed atheist Sam Harris, transhumanism aims to provide a much clearer moral and philosophical impetus to the current techno-scientific enquiry. Avoiding nihilistic posturing, transhumanism, a socio-philosophical movement aimed at elevating the human condition through technology, urges the importance of moral imperatives in the technologized world.

One of the foundational moral imperatives of transhumanism is the Neo-Protestant 'proactionary principle' initially developed by Max More, which favours a considered risk-taking approach to science and technology, as opposed to the Hippocratic 'above all do no harm' principle. Transhumanism attributes the meaning to technology, partly through the value of the technology itself (humans becoming enhanced with the technology created) and partly through the process of engaging in scientific enquiry, overcoming adversity and forging characters in the flames of failure (transhumanism embraces the belief that true virtue is achieved through creative destruction and not all endeavours will be successful). Whilst transhumanism can be accused of assuming an 'enchanted' world like religion itself (e.g. imagining the worlds we could live in, science fiction), it openly appeals to the scientific method, including publicly declared predictions that are informed by facts. Whilst transhumanists contemplate the dangers of existing and future technologies, and embrace the opportunities so created, they have an utmost understanding that the living conditions and social changes so created require an overarching moral code alongside the progress in technology.

Whilst science is capable of disenchanting religion by providing factual explanations where belief had sufficed, technology is re-enchanting the transhumanist world, giving meaning where there was none. (After all, if you live to die, what is the point in living? Hence the transhumanist focus on immortality.) Transhumanists adore technology as it gives value to being and becoming - whilst religion has increasingly distanced itself from technology, as it pushes death away, which to religious believers strips the life of meaning.

There is now an urgent need to provide a meaningful techno-positive explanation to the world in the midst of the Covid-19 pandemic. With technology replacing human contact in the face of self-isolation and with the acceptance that only technology and science (in this case, ventilators, tests, telemedicine) can keep us alive as individuals and functioning as social beings, the time is now for society to come to terms with our dependence on technology. For, as long we do not commit to a technology-based human enhancement system, we will always be blindsided by nature and playing catch up with our basic biology.

\section{Disenchantment and the Meaning of Science (Sharon Rider)}

I would not advise a re-enchantment of higher education or a renewal of the marriage of the scientific endeavor and religion, if by that one means that we can or should ignore or repress the rationalization of human life associated with modernity. It seems to me, for reasons that I will sketch below, that it would mean surrendering intellectual 
integrity. Having said that, recognizing and acknowledging the limitations of science and technology mean leaving questions of meaning where they belong, namely, to the individual who has to take a stance in his own life and stand for his own values. The role of higher education then is largely to make explicit to him just what those values are, and, importantly, what they entail. My arguments are inspired by what I judge to be the still greatest articulation of the dilemma of modern thought, Max Weber's lecture 'Science as a Vocation' (Weber 2004).

Weber argues that in the modern world, one can justifiably ask: 'What is the vocation of science within the totality of human life and what is its value?'. It can no longer be to seek some unadulterated true being (the Ideas) as it was for Plato, the secrets of nature as it was for Bacon, or religious insight as it was for Swammerdam. The notion that science can lead to happiness, he thinks, can only be entertained by 'some overgrown children among the professoriat'. The reason is quite simple: we can't really believe in such things anymore without diminishing the intellectual demands that we, as scholars and scientists, should place on ourselves. It would mean pretending not to know what we in fact know, which, for Weber, is a cardinal sin in academic life. Citing Tolstoy, Weber reminds us:

Science is meaningless because it has no answer to the only question that matters to us: 'What should we do? How shall we live?' The fact that science cannot give us is this answer is indisputable. The question is only in what sense does it give 'no' answer, and whether or not it might after all prove useful for somebody who is able to ask the right questions. (Weber 2004)

Given the irreducible plurality of worldviews, what academic instruction can do is provide clarity with regard to the meaning of the stance that one takes, one's ultimate values, and what 'can be inferred consistently, and hence also honestly', from that or that fundamental ideological or religious commitment or philosophical position. It is a matter of what can and cannot be inferred without doing violence to reason. He writes: 'To put it metaphorically, if you choose this particular standpoint, you will be serving this particular god and will give offense to every other god.' (italics from original) The point of higher education is to compel, or at least help, someone 'render an account of the ultimate meaning of his own actions', by making explicit to the student the circumstances and commitments involved in his moral orientation, 'to create a sense of duty, clarity and a feeling of responsibility.'

\section{Material Proof: Between Blessing and Burden}

\section{Abu Hanifa and the Dahriya (Ibrar Bhatt)}

At some point in the middle of the Eighth Century CE, by the banks of the River Tigris in Abbasid-ruled Mesopotamia, a debate had been scheduled to take place. The renowned Islamic theologian Abu Hanifa had been called to debate about the purpose 
of the universe with a leading member of the dahriya ${ }^{1}$, a name given to those who believed that the course of time (Arabic: dahr) is all that governs human existence. The dahriya were portrayed in the Persian and Arabic literature of this period as materialists who denied the existence of anything that cannot be perceived by the human senses. In modern terms: atheists.

As the dahri scholar and his associates waited, it became more and more apparent that the Imam was running late. Very unbecoming for a man of religious repute. Hours passed and the group of devotees awaiting the Imam became anxious, while the dahris and their representative became more emboldened. They even dared to suggest that perhaps the Imam had decided not to take up their challenge to debate about the topic due to fear of losing. Finally, the Imam arrived, and was immediately questioned about his lateness. He replied in the following manner:

As I reached the banks of the River Tigris, I needed a raft to get across and none was available. I continued to look around and decided to wait for a raft to assemble naturally over the course of my wait. Eventually, low and behold, the wind, water, and other forces of nature brought together all the required pieces of wood and nails to form a perfectly assembled raft for me to get across. That is why I am late. ${ }^{2}$

His opponent argued, understandably, that it is impossible and ridiculous to even suggest this as a cause of the Imam's lateness. Elements of nature do not assemble on their own into perfectly designed objects in this way for us to use. Rather, a raft suitable for crossing the River Tigris must require a maker. Abu Hanifa countered by asking why his story is uniquely impossible and ridiculous compared with the main foundational thesis of the dahriya: that the entire universe and everything within it is not ordered by a creator for whom there is a preponderance of 'signs' (Arabic: ayat).

The idea of 'enchantment' is central to Abu Hanifa's argument: an enchanted view of the universe is necessary to answer the 'why' question of its existence, and metaphysics allows room for answers related to the origins of consciousness and of the universe itself. To Abu Hanifa, the chief metaphysical question here is: Why is there something as opposed to nothing? Abu Hanifa's subsequent argument is based on evidence that is not 'beyond reasonable doubt' ${ }^{3}$ - such as that which would have satisfied the dahriya - but rather one that is based on the preponderance of evidence (ayat) and therefore grounded in reason but also requiring faith and wonderment. Abu Hanifa's view demonstrated an inter-connectedness between religion, philosophy and science that was absent in the dahriya's disenchanted view of the universe, and therefore lacking in tools to explicate the mysteries of its existence.

In modern times, religion, philosophy, and science are much less interconnected, and the enchantment of a faith-based worldview, the type that Abu Hanifa was espousing, is one that opens up the vitality of human and non-human interconnectedness: That all objects (people and things) serve a purpose worthy of contemplating. Today, perhaps New Materialism can allow us to make room to question and probe

\footnotetext{
${ }^{1}$ Literally translated as 'those of the time'.

2 The account is narrated in Manaqib Imam Azam, by Mawfiq bin Ahmad Makki, translated by Owaisi (1999). Some have even attributed the account to the twelfth century mystic Abdul Qadir Gilani. I rephrased the account for the sake of brevity.

${ }^{3}$ According to the classical view of Muslim scholasticism, as stated in the Kalam Cosmological Argument, for belief to be sound it has to be grounded in reason (Hanson 2017).
} 
anthropic 'coincidences' (like the materialization of a magical raft?), without an unattainable burden of material proof.

\section{From Science's Enchantment and the World's Disenchantment to the Re-Enchantment Beyond Duality (Abdassamad Clarke)}

The two interconnected arguments that religion, philosophy, and science have unnecessarily become disconnected from each other, and that, in the process, the enchantment of the old religious worldview has been lost, can better be expressed thus: A single worldview, without division except for the sake of intellectual delineation, has been challenged by the exclusivist claim of science to enchantment, to which the subsequent disenchantment of the world is an accidental bi-product.

When we talk about science, we are not talking about the Greeks, Babylonians, or the Arabs but about something that arose in post-Renaissance Europe during the Reformation for very particular reasons, with Galileo, Descartes, and Newton being decisive in their input. Although the experimental and observational approach is most prominent in our minds, their major contribution was to continue and extend the axiomatic work of Euclid (see Heidegger 1967) into the physical sciences, work that continues to this day. In a time in which religion was shaken by the devastatingly hot political, military and theological conflicts of the Reformation, this cool, indeed cold, approach was increasingly attractive to Europeans. This attraction was best expressed by Bertrand Russell who later said: 'I wanted certainty in the kind of way in which people want religious faith' (Russell in Kline 1982: 229-230). And it was certainty that the axiomatic way promised, with its definition of terms, statement of self-evident axioms that need no proof, advancement of hypotheses, careful proofs, and resultant theorems.

All three men, Galileo, Descartes, and Newton, were undoubtedly believing Christians. But what they did not anticipate was that what had not been established by this rigorous approach fell into doubt, i.e. non-mathematical philosophical approaches, theology, and indeed the great majority of everyday human experience. They could never have imagined Laplace's response when Napoleon asked why he had not mentioned the Creator in his work on celestial mechanics, and he said, 'I have no need of this hypothesis' (Kline 1982: 73). Nor could they have imagined the meltdown that was to occur in pure mathematics itself, the very core of science. Thus both the world and science, the very road to certainty, had fallen into doubt.

However, to understand the disenchantment produced by the division between our tripartite schema of religion, philosophy, and science, it is necessary to remember that science was originally 'natural philosophy', and that we actually have a bi-partite schema, a duality. Rather than seeing the necessity to reconcile two competing narratives, what we should address is the duality that lies at the base of the Western worldview (Palmer 2012) looking for its long hidden non-dualistic core that can restore wholeness.

\section{Omnipresent God, Missing Angels, and Avoidable Reductionism (Morteza Hashemi)}

It is a simple but interesting sociological observation that angels have been largely excluded from the everyday life of even highly religious communities for over a 
century now. This observation holds for many contemporary Muslim and Christian communities, both in Europe and the Middle East. Take as an example the abandonment of angels in Shia Islamic forms of art in Iran. Those Shia angels appear to be the victims of a classically Weberian process of disenchantment. Angels were traditional presences in Persian literature, popular stories, and even Islamic philosophy (Walker and Morgan 2011). Yet their depiction changed in around the sixteenth century, through the interaction of Iranian artists with their European counterparts. Iranian artists adopting elements of the more naturalistic, Renaissance style, which they skilfully synthesized with the traditional art of the Persian Safavid court.

Human-like depictions angels began to appear as a staple of that synthetic genre. The angels of artists, such as Mohammad Zaman, in the eighteenth century were, more or less, human-like inhabitants of the world. After the Safavid era, the Qajar dynasty came to power between 1789 and 1925. It has been shown that at this time the wings of the painted angels became smaller, and more like those of birds (Safarzadeh and Ahmadi 2014: 52). In a way, the angels of that era started moving towards the beasts found in Jorge Luis Borges' magical realist 'fantastic zoology'. In fact, Borges was himself aware of the disappearance of these divine beings. In 1926, he wrote that angels are the only creatures of our imagination which have survived so far, unlike such monsters as demigods, unicorns, and centaurs. 'We must not be too prodigal with our angels; they are the last divinities we harbour, and they might fly away' (Borges and Weinberger 1999: 19). The angels of Iran flew away in the late nineteenth century. Today, one cannot find many discussions of them even in the religious seminaries or published works in the holy cities of Qom and Mashhad.

Before happily confirming the Weberian framework as a way of understanding the departure of the Persian angels, we need to remember that Iran is a country which experienced a religious revolution in 1979. There is no empirical data showing any tendency towards the demise of religion as a political and social force in the Middle East. Not only is God still alive in Iran but also according to a Pew Research Center (2020), 'most Iranians believe religious figures have a role to play in government, but they are divided on just how big that role should be'. Thus, by no empirical measures can we call modern Iran a disenchanted world. God and his followers are omnipresent and shape everyday life.

God is not less invisible than angels, but neither science nor philosophy has been able to replace the Shia God of Iran. My suggestion is that there is an intrinsic simplification, reductionism and Eurocentrism in the concepts of disenchantment and re-enchantment, which make them unfit to explain the empirical facts of religion. In Iran, the divine beings taken as a whole have in part been abandoned, but in part strengthened in recent times. There has never been any simple, one-way process. The experience of the past century proves that a postdigital world could easily inherit the Eurocentric theoretical frameworks and reinvent its inherent reductionism. Alternatively, it could improve the tools we use to question such concepts and conceptions, by encouraging our contemplation of the complexity of the religious phenomenon. That is what we can (and should) learn. 


\section{A Plea for Greater Mutuality and Valuing of Experience from a Minister of Religion (Andrew Bevan)}

Theology, science, and philosophy share, at their roots, a human quest for understanding. The Western traditions might trace a development of thought and practice from Aristotle, via Aquinas, Newton, and others and into the nineteenth century. In each of these fields of human endeavour, the lived experience of a practitioner is a formative part of their understanding, whether or not that is acknowledged. The process builds on the work of those who have gone before and, at each growth point, someone's imagination exercises a determinative role in the generation of new knowledge. Perhaps we are reluctant, or just slow, to appreciate this gift as and when it occurs. Very few, like Einstein, gain widespread recognition for initiating a paradigm shift but, hopefully, the academy recognizes it every time a doctorate is awarded, without fear or favour, and rigorously defended, including against all financial and political influence.

When I studied mathematics, we had a tutor who struck me as very arrogant. He may have adopted this persona to remind his students of the rigour of the subject but it left an impression which clashed with my belief that the more we know, the more we know that we do not know. For me it is somewhere in the tension between knowing and not knowing that religious experience occurs. As a discipline, theology takes this experience, and religious practices, sufficiently seriously to try and understand them. Similar curiosity and a sense of responsibility motivate serious work in the other disciplines. Who would dare to differentiate the wonder experienced by someone who believed they had encountered the divine from that experienced by a biologist seeing the intricate life revealed by their microscope or a mathematician observing the severe beauty of a good theorem or equation?

For much of recorded history, institutional religion asserted its hegemony, often by brutal suppression of heresy and hierarchical control of knowledge. This stranglehold is no longer tenable in much of the postdigital world but there remain some strong and widespread exceptions. A truly plural context includes space for myriad accounts of experience and understanding. One aspect of our postdigital context is the capacity to process enormous amounts of data to create an overwhelming amount of information. The size and speed of these processes seem to have an inherent power but I believe all this information, by itself, does not confer understanding. Control of the information has endowed some of the richest people on earth but access to it and the uses to which it is put are fiercely contested. The open question whether it will be for private gain or the common good remains a challenge to us all: Will the mistakes of the past be repeated or not?

In terms of mapping the territory, and identifying possible resources for the future, a multi-disciplinary approach seems to be imperative, involving academics and practitioners:

[This way of working recognises] knowledge as embedded and material rather than distant and abstract taking into account non-specialist perspectives, material practices and the insights of other disciplines. A willingness to acknowledge the other levels at which humans function, those of feelings and instincts as well as what is normally termed the logical and autonomous, and then the realisation that 
one is always already in relationship with the non-human in shifting and evolving assemblages. (Reader and Evans 2019: 35)

\section{Postdigital Poetic Re-Enchantment (Eric Trozzo)}

The postdigital age is marked by the increased seamlessness of integration of the digital into our experienced reality, increasing access to data and relationships. In order to provide frameworks of meaning to the vastness of this now-accessible experience, new metaphors that can speak to such an expanded engagement are needed. A siloed approach to the creation of metaphors between spiritual, philosophical, and scientific aspects promotes a fragmented and conflicted approach to the world. A multidisciplinary approach to the creation and consideration of metaphors, on the other hand, allows re-imagining our engagement with the world.

Within the realm of religious thought, Caputo (2013) contrasts theology that understands itself to be presenting objective or factual statements with radical theologies that seek the event which stirs within the event of faith (termed 'theopoetics'). Theopoetics seeks to speak of events or callings harboured in the words for religious experience which cannot be spoken of directly, but rather requires an active creation of meaning through the limits of available words. Theopoetics is a re-envisioning of human life spurred by the hope of possibility that cannot be expected or explained through attempts at objective logic.

Theopoetic approaches find amendable dialogue partners in New Materialist thinkers who recognize the importance of metaphor for scientific inquiry. There is a growing recognition, for instance, of how conceptions of evolutionary theory are shaped by the metaphors of trees and ladders to understand it. These metaphors have shaped the discussion in terms of hierarchy in growth towards ever-greater complexity as continual improvement. Yet biology has uncovered examples of the 'de-evolution' of species towards greater simplicity that run counter to the narrative of progress and upsetting the helpfulness of dominant metaphors (Hejnol 2017).

As scientific and religious thought come to sharper awareness of the metaphorical nature of their constructions, it allows for a dialogue about how which metaphors come to the fore shape understandings of reality. Implicit in this is recognition that no single approach has an exclusive claim to an 'objective view'. The contribution of theological language is to attend to the excess or surplus that always lingers beyond any description of life, as well as to the recognition of the interwovenness of embedded relationality that calls us to care for the Other. The recognition in New Materialist thought of science's own metaphorical nature allows for a sharing of metaphors, particularly of experiences of excess and relationality. For instance, Keller's feminist relational theopoetics speaks (2015) of the mysterious excess that calls forth ethical and religious connection and obligation to one another using metaphors drawn from quantum entanglement (2015). Following her approach, we can see the value in crossing disciplinary boundaries in fostering a dialogue to formulate new articulations that can produce new insights.

The theopoetics production of metaphor is an act of re-enchantment. It recognizes the historical language speaking to the spiritual and relational experiences of a particular faith community, as well as the legacy of twentieth century 'de-mythologizing', 
while seeking to sing a new spiritual and relational insights for a new age. This is not a rejection of a sense of an objective reality but rather a recognition of the poetic nature of human meaning-making through every interaction with that reality.

\section{Why Does It (Not) Feel Empowering?}

\section{Faith and its Disenchantments: A Very Short Feminist Critique (Alison MacKenzie)}

I am from the Isle of Lewis, a remote island off the North West coast of Scotland, where the Gaelic culture only just survives and the Protestant Church holds sway. I had a strict upbringing in which unquestioned belief in scripture and church attendance was a virtue. I was not, however, 'enchanted' with scripture or with God for that would have been a devilish, if not papish, state; but I did fear God. Until I was in my teens, I never questioned either the church or faith in God, and I did not question the status of women. Women were quietly spoken, respectful, and silent in church or when men were present. Men, I was brought up to believe, headed households. Women's work was in the home, and women, because of Eve's seduction, had brought sin to the world, which justified our inferior status. However, for me, Eve represented reason, a woman who wanted to know. Adam simply followed her, passively, and without thought, despite God's direct injunction to him not to eat of the Tree of Knowledge.

Both had rested in a state of bliss and enchantment, feeling no fear, shame or jealousy; no compassion, pity, or sympathy. A garden inhabited by only two people living a life of no moment until a snake slides along to hiss his seductions to Eve was a state of Edenic stupor that evidently did not satisfy Eve. 'What's the point of having a mind?', I asked. 'Why put the tree there and say “don't eat the apple”?', 'Does God not understand the psychology of the creatures he created?' The serpent did, but tempted not with material riches, but with the promise of knowledge.

What the allegory of the Fall unleashed, however, was far from enchanting. I cannot be enchanted with a book that demands faith in the impossible and the unknowable, and which is riven with misogyny. Exodus teaches that Eve brought sin and death, and precipitated the fall of God's perfect, if dumb, creation. She was punished and relegated to not-quite human status, while Adam, who obeyed, was accorded superiority and took advantage of the knowledge she released by that bite. Eve's unfortunate daughters were bonded in marriage, cursed to suffer the pain of birth, and play the role of a minor dependent on man's good will in silence and subjection for all her material wants; she was made incompetent and powerless, while incarnating all the world's temptations in her flesh. There is no charm, delight, or magic in regarding a class of human as the disposable property of men because they symbolize sin.

Can there be equality of status between philosophy, science, and religion? No. The means by which each produces knowledge is different. Faith and solipsistic argument do not use reason and do not require evidence. Faith is the negation of thought, a commitment to belief in the absence of evidence, and a form of irrationality that, with respect to my particular concern, has served men well, while degrading the status women to men's mere means. Science and philosophy rely on reason, observation, and panoply of methods and theories to make knowledge claims that produce evidence, are subject to scrutiny, and that are revised in the light of 
evidence: the knowledge claim is contingent and susceptible to further refinements. Belief in the possibility that some proposition could be the case must be proportional to carefully gathered and assessed evidence. One is free, of course, to be enchanted by the processes and effects of faith, but it is not a valid cognitive process with respect to epistemology, and should not be accorded the same status as philosophy and science.

\section{Empty Sanctity: Ruminations on Christianity and Whiteness (Jared J. Aldern and Cheryl E. Matias)}

\section{Whiteness, Racial Shame, and Jesus}

It has been said that cleanliness is next to godliness. If that is so, why do those of the European diaspora possess such debilitating racial shame amidst the sanctimony, purity, and cleanliness of whiteness? First, it's important to understand the nature of the shame in question. Shame takes many forms (see Thandeka 1999), but the racial shame we speak of is Colonial, Precolonial, and indeed Postcolonial because it is unique to white-identifying people who have inherited, alongside unprecedented wealth and power, a unique guilt complex that saddles their racial discourse at every turn (see Baldwin 1998). Why the longevity? Of course it is because this guilt derives in part from religious tyranny - from the shame of birth which must be alleviated by giving of oneself to Jesus Christ alone, to storytelling about the racialized other who is perpetually in need of saving by a white heterosexual male Jesus. White shame, then, is emblematic of a long historical and biblical retelling of lies.

\section{Education, Emptiness, and Chaste}

The purity and sanctity of the Virgin's whiteness could not be penetrated to spawn this ultimate teacher, kept instead in white chastity. This is the story of white Jesus. The Virgin should not be plundered by the filthy Others of the world, who may worship Him but never project their image onto Him, the way the white of European diaspora has. He (Capital H) must come from Thee Almighty, not he (small h), which would be un-sanct and un-sanitary-notice the common roots meaning saint. If He came from un-sanctity, He would not be He. Therefore we must behold $\mathrm{He}$ as The Way or be forever led astray by our innate unsanitary unsanctity. A nearness to God is considered by Weil (1951) to be a great treasure in humility, allowing someone to be a good student, who, as Freire (2011) described, presents themselves meekly as a receptacle to be filled by the teacher. Or was there no sex after all? For, as Fanon (1952: 142) tells it, ' $[\mathrm{t}]$ he intellectual gain calls for a loss of sexual potential'. She, the Virgin Mary, was merely the vestibule to the real womb - the tomb. No question is made of the sanctity of planting a seed in an unwitting female recipient. She must sacrifice by allowing herself to be used for the good of mankind and take backseat to her Holy Son giveth for her, to her, and through her, to save her from herself. She is womankind. She must subsequently give herself again to Him who she brought into being in the first place. The purity was always only skin deep; the chastity always empty. Coming to white Jesus is already a fool's errand. 


\section{Artefacts of Western Thinking (Georgina Tuari Stewart)}

The postdigital context facilitates the process of destabilizing truth, even while it appears to democratize knowledge by making knowledge more freely available. The Internet has the effect of defining the boundaries of 'what is known' so in the postdigital era the means of knowing has been captured by private interests. Science has repeatedly shown itself to be completely in thrall to profit. The current global owners seem intent on using up the rest of nature in their remaining few years. The findings of research into misinformation campaigns directed towards the 2020 US Presidential elections call into question the last remaining shreds of the notion of 'Western democracy'. The acceleration of climate change, the rise of global pandemics, and visible signs of coming mass extinction are all symptoms of out-of-control thinking that humanity can separate itself from the rest of the biosphere: an idea that arose in the fabled 'West' (i.e. the place of origin of modern science and the pinnacle of human evolution) and is out of step with every other form of cultural knowledge base.

The globalized Anglophone academy we see today is the product of a history of several centuries in duration, over which time it has defined itself and developed its canon by the process of excluding Indigenous and other forms of knowledge, including religion. This process of exclusion largely accounts for the 'disenchantment' part of the cycle. The disciplines consolidated as their archives grew more institutionalized and self-sustaining. The domains of the academy refined their boundaries, represented and manifested in the central criteria of each, and their relevant methods of inquiry. The structures of the modern academy developed alongside the process of separating the world of writing into science and literature by the late 1800s. The development of science is a strategic deployment of the power of the written word as discourse in Foucault's sense, as the mediation through language of power/knowledge and the construction of truth: the claim science takes upon itself. Contemporary science is the paradigm of the power of reductionist and technicist thinking. In one sense, what is happening today can be glossed as coming to the limits of Western thinking.

The 're-enchantment' arises as these limits become more and more difficult to ignore. An example is the increasing popularity in recent decades (in ecology, anthropology, philosophy, education, and other fields) of advocating for Indigenous knowledge as the best hope for increasing the security of humanity's future on this planet. Such claims have been short on detail and it is difficult to demonstrate their effectiveness, given the frameworks of technicist knowledge pervading every sector of economic activity in the global economy. But attention to the perceived 'value' of Indigenous knowledge continues to grow. In Aotearoa New Zealand, for example, a policy about Māori knowledge applies to all public sector research funding.

Indigenous knowledge has gone from being subjected to exclusion and Eurocentrism, to a contemporary context of ongoing appropriation that amounts to a symbolic form of neo-colonialism. From an Indigenous perspective, the cycle of disenchantment and re-enchantment between science, religion, and philosophy may amount to no more than an artefact of the Faustian bargain of Western knowledge: the pursuit of which involves accepting a reductionist, technicist notion of truth that eventually becomes the same as a lie, or a boot in the face. 


\section{Re-Enchanting the Indigenous Lens (Carl Mika)}

A plausible argument is that the digital age produced a particular subjectivity for indigenous people. In many respects, the digital age is no different to the first onslaught of a highly ordered, constrained world, introduced with the written alphabet (Aranga, Mika, and Mlcek 2008). By highly ordered, I mean that things were placed into rigid categories that are foreign to a more holistic indigenous mind-set. There is a distinctly Heideggerian (1977) flavour in that view, except that indigenous peoples might propose a different rupture than Heidegger's (see Mika 2017). The subjectivity that builds from being watched, for instance, is one that comes from the strict discipline of the body, which in turn arises from a separation of things in the world; with indigenous peoples, the construction of the self occurs through the construction of all things in the world, due to their interrelationship (Deloria 2001). Thus, although it is possible to focus on the indigenous human self and how it has been disconnected through digital's many forms, in fact that fractured selfhood is no different from the fractured self of the world in total. To return to that brief example of surveillance, all things in the world are constrained and watched, even though it appears to be a deep concern of the human self. More specifically, in Maori thought, surveillance is an entity along with many others that suffuses throughout all things (Mika and Stewart 2015).

In the postdigital epoch, it is our challenge to reconcile modernity's entrenchment within indigenous pre-modern thought and practice. One way of doing this is to acknowledge that, while the disenchantment- the anaesthesiathat came with modernity is irreversible, the basic way in which modernity constructs things in the world can provide the platform for mystery. In itself, it is un-mysterious, but creatively encountered, it transforms into something else. For the indigenous subject, the ability to re-enchant things in the world is extremely important, and signals a step in countering colonization, if not completely undoing it.

Approaching ideas and things in this way is perverse, to the extent that it may be in bad taste. Ultimately, any indigenous resistance to disenchantment is a big step because, like indigenous claims to indigenous territory or language, it often asks for an irrational response. This is especially true for philosophy because one is basically left to creative thought that does not necessarily conjoin with rationality at all. Thus, to re-enchant is, in effect, to de-rationalize. In academia, the re-enchantment can take place through deliberately misreading another's utterance (a case of hearing, not listening); inappropriate or dark humour; transcending the given meaning of words and considering a holistic backdrop to them; playing with words, and so on.

But these interventions are never enough; the process is continuous. The digital epoch for indigenous peoples has bolstered the numerical view of the world that did originally arrive with the western alphabet; the digital (in the sense of the mathematical) now sits behind the indigenous lens, not simply in the world of appearances. Re-enchantment, whether through resistance or derationality, is only ever a work in progress for the indigenous subject-an ongoing challenge which acknowledges the inability of the self to really grasp what lies behind one's indigenous (but digitalized) lens. 


\section{From Description to Humanization: A Dialectics of Liberation (Peter McLaren)}

We human beings weren't born with a certain set of established hermeneutical frameworks; that's very clear. We were socialized into them. The factors that contributed to this socialization are legion and would require a broad excursus into the history of science, philosophy and religion as they developed within conditions of feudalism and more recently, authoritarian market capitalism with all its attendant bureaucratic modulations. One important project of our times is to consider re-socializing our theoretical approaches to religion, science and philosophy, to explore how they are conceptually entangled or otherwise intimately connected in a manner that enables us to look at science, religion, and philosophy from the perspective of creating a new beginning, a new society, a new world - in short, a social universe that is not anchored by the value form of labor but rather operates on sound socialist principles. Reason alone, after all, cannot transcend alienation in order to put us on a path of liberation. Only human praxis can achieve this.

For Hegel, the dialectic of self-consciousness is what moves history forward. And it is this historical movement of humanity through the sublation of contradictions that brings us closer to discovering possible new beginnings for humankind. The externalization of thought (creating ideas and objects of thought or objectified thought) and the transcendence of this externalization occur when thought returns to itself by knowing itself. This self-thinking thought- thought that thinks itself-is able to identify contradictions but is ultimately incapable of transcending alienation (Hudis 2005). Marx maintained that this dialectic of consciousness - this self-thinking thought as described by Hegel - cannot transcend alienation because it is ultimately disconnected from aspects of our species being, our corporeal, embodied nature. The subject as identified by Hegel is dehumanized and ultimately reduced to abstract thought, thought that has been denatured, deracinated, and thereby made inhuman. By contrast, Marx views history as a dialectic of labor, as the historical movement of laboring humanity, the selfactualization of the totality of human powers. For Marx, disembodied thought cannot be the subject of history (Hudis 2005) since human actuality is not a product of thought; thought is a product of human actuality. Because thought is a product of human actuality, it is therefore possible, according to Marx, to consider the transcendence of alienated labor (Hudis 2005). The answer to the exploitation and alienation of human labor is not the reconciliation of thought to itself but rather the actual abolition of the alienating determinations of the external world (Hudis 2005).

Science, religion, and philosophy all have the potential to be praxis oriented, to selfconsciously work towards developing a more liberating society through the negation of the negation. This potential made it imperative for Marx that philosophy move beyond describing the world in order to change the world. Following this imperative we can stipulate that religion, philosophy and science must move beyond the idea of understanding the world, towards a politics of praxis, towards the idea of transcending our alienating world in order to change it. But it is impossible simply to 'apply' Hegel's concept of the negation of the negation, one has to reconstitute it within a larger philosophical framework that accommodates science and religion. And concretizing absolute negativity as a new beginning must be supported by a philosophy of liberation that illuminates what a postcapitalist society might look like (Hudis 2005). We must unite revolutionary subjects with science, with religion, and with philosophy in such a 
way that we can posit a viable path to liberation, one which can be achieved through a unity of the embodied or 'enfleshed' subjects of revolt with the 'idealist' philosophy of liberation that is rooted in the dialectic of absolute negativity (Hudis 2005).

Science, philosophy, and religion, when grasped dialectically through an historical materialist analysis, can illuminate a new beginning for humanity since it is the seedbed of creativity (McLaren 2015). This stipulates that thought — and here we are affecting a transdisciplinary motion by referring to philosophical, scientific and religious thought-must achieve more than an attempt to correspond to reality. Scientific, religious, and philosophical thought must instead be grasped dialectically in order transform reality. Another way of putting this is to say that human beings must be at the center of religious, philosophical, and scientific thought. The negation of the negation makes it possible to recognize (or 're-cognize') that human beings are the source of negation and the shapers of history. Such recognition situates human beings as the point of departure of philosophy, science, and religion, as well as its point of return, a point of transcendent consciousness capable of transforming the world in the interest of creating a social universe freed from value augmentation and wage labor and grounded in freely associated labor.

\section{Postdigital Enchantments and Their Enemies}

\section{Distraction and the Enchantment Spectrum (Derek R. Ford)}

Theorizing the postdigital era consists, at least in part, in grappling with the ways in which the contours of social relations have been, and continue to be, reconfigured. The very concept of the postdigital itself names one of these reconfigurations: the contours between the analogue and the digital have shifted to such a degree that a new designation is justified, one that is, importantly, a question rather than a theory. One set of modified social relations are those of enchantment, disenchantment, and reenchantment, relations that are both pedagogical and political. They are pedagogical in that they concern the fundamental processes of education - namely, stupor, knowledge, and questioning - and they are political in that they are the site of struggles over power.

Dominic Pettman's (2016: 27) examination of the rearrangement of attention and distraction via social media technologies provides a helpful map for this problematic. Where is the opening of quotation marks? Rather than redirecting attention to something else, distraction is now a form of attention; a phenomenon is composed of millions of tiny moments of engineered attention (or vice versa)'. Distraction is no longer when media corporations highlight trivial happenings instead of substantial issues. Instead, the substantial issues themselves spin off in a multiplicity of directions - some of which might be trivial — each of which are flattened. Click on any hashtag and you will know what Pettman means. Dominant systems of power are less concerned about the content we're looking at than they are about the variety of forms related to that content. The contradictions that could galvanize political struggles are thus dulled, 'not only because they come so thick and fast, but because each one is rendered equivalent to the other by virtue of its place in the Feed' (36). That place is, of course, determined by the opaque and ever-shifting algorithms produced by the corporate giants that own social media platforms. 
By subsuming attention within distraction, the spectrum of enchantment is both intensified and weakened. It's intensified in that there is a limitless stream of questions to explore and unknowns to know, but it's weakened in that the force of the spectrum is blunted to such an extent that the foreign and new never impose an interruption or a break. Stupor, or the absence knowledge, is transformed into ignorance, or the capacity for knowledge; wonder, or the process of endless questioning, is reduced to research, or the production of new answers. The political struggle over the production, ownership, and use of social media technologies thus necessitates an educational struggle to reclaim the radical disorientation that defines each aspect of the enchantment spectrum.

\section{Trust, Faith, Critical Questioning, and Interpretation Of Evidence (Tim Fawns)}

Through their shared history, science, religion, and philosophy have been used to open and close ways of thinking. Science has opened up domains of study, yet one of its goals is also to produce universal explanations that remove doubt. Philosophy emphasizes critique (of beliefs, assumptions, ideologies), and extends beyond hard evidence, yet its thought experiments are heavily constrained by rules of logic. Religions often encourage 'followers' to question themselves and others, yet may also defer knowledge to authorities (leaders, deities), suppress questioning, or insist upon faith-based answers.

Philosophy, at its best, extrapolates on the implications of particular cases if they are right, but remains open to them being wrong. Thus, when pilgrims in Qom, Iran, licked a shrine in the belief that they would be protected from the Covid-19 virus (Diseko 2020), or religious leaders encouraged followers to congregate in packed buildings (Alesse 2020), share spoons, and kiss monuments (Roth, Walker, and Phillips 2020), it was scientific knowledge, and not philosophy, that called such acts out as wrong, rather than right. On the basis of religious knowledge, these acts were ways of fighting the virus, backed by faith that the pious cannot be infected through holy materials and environments. Curiously, the dissemination of scientific knowledge on which accusations of wrongness were based, requires trust in scientists, accepting their interpretations over alternative explanations. While science cautions against blind trust, appealing to methodological rigour and empirical evidence, in practice, 'the science' is often held out as unassailable truth to further agendas and maintain control (see governmental responses to Covid-19, e.g. Devlin and Boseley 2020). Philosophically, both of these scientific and religious knowledges could be right (or wrong) because both could be satisfactorily explained in their own terms (e.g. increased rates of illness and infection data might be accounted for as a test of faith).

While we might characterize the above religious beliefs as dangerous, science and philosophy are also dangerous in isolation, because they are bound to ethical but not moral principles. A strength (and, perhaps, also a weakness) of religion is that it provides principles that inform moral action. Each domain produces knowledge and understandings that cannot adequately be explained by the others. Each was, arguably, born from curiosity and wonder, traits that, as an educator, I encourage in my students. It is a conundrum, then, that wonder, and enchantment with knowledge, might be diminished by finding definitive answers or accomplishing precise, pre-determined outcomes. Perhaps it is fortunate, then, that the complexity across and between each domain seems destined to always require something out of reach of the rational, 
objective and empirical. Through an appreciation of complexity, knowing is never finished, and this allows both a re-enchantment of definite (and, thus, dead) knowledge, and a disenchantment of apparently unassailable truths.

For me, this is the foundation of a postdigital perspective. The digital is understood as complex, entangled with the social, material, and political. As such, algorithmic analyses of reductive, digital data (as in some learning analytics approaches), and the crude categorization and compartmentalization of knowledge and people (e.g. in claims about learning styles or digital natives) close down important ways of thinking. Similarly, attempts at controlled, scientific study of the effects of interventions on educational outcomes, while they may seem to bring clarity, come at the expense of context, diversity, and expert judgement (Goodyear and Ellis 2008). Through attempts to find 'best practices', 'optimal methods', and technological solutions, these acts violently shape concepts like learning, engagement, attitude, reflection, empathy, and more. That is not to discount these methods altogether, but to recognize the claims they produce for what they are: broad and blunt and imprecise; abstracted from context; simultaneously enchanted and disenchanted by representing themselves as more than they are, and by missing the rich and dynamic complexity of the interrelations of people and their social, material, and digital environments.

What we can we learn about complexity and uncertainty from the interrelation of science, religion, and philosophy? For one thing, by taking multiple perspectives, we can strive to hold open our ways of knowing, through a balance of trust, evidence, logic, and critique.

\section{The Enchantments of Data Science (Jeremy Knox)}

In contemporary times of unfathomably powerful technology companies (Srnicek 2017), astonishing scandals involving social media manipulation (Ward 2018), enthralling accounts of 'surveillance capitalism' (Zuboff 2019), and the mesmerizing narratives of a coming AI-fuelled ' 4 th industrial revolution' (Schwab 2017), we appear to be at our most enchanted with the digital. In an era where all digital technologies appear geared towards some form of data collection and processing, we are undoubtedly captivated, just as much by the promises of personalized convenience and precisely predicted outcomes, as by the perils of increasing surveillance and the loss of privacy. However, both our utopic obsessions with efficient Artificial Intelligence-infused societies (involving self-driving cars, smart cities, and emancipation from labour), and our dystopic visions of data-driven Orwellian authoritarianism (or indeed Huxleyan media-driven apolitical pleasures) ${ }^{4}$, are grounded in mythology: 'the widespread belief that large data sets offer a higher form of intelligence and knowledge that can generate insights that were previously impossible, with the aura of truth, objectivity and accuracy' (Boyd and Crawford 2012). In other words, an assumption that data-driven technologies actually function as promised drives both our sanguine and our suspicious outlooks. However, as a recent study demonstrated, machine learning techniques were not able to demonstrate anything approaching accuracy in the prediction of life outcomes, utilizing data from a 15-year-long research project

\footnotetext{
${ }^{4}$ For more useful discussion of Orwell's and Huxley's competing visions of dystopia, see: Postman, N. (1985). Amusing Ourselves to Death: Public Discourse in the Age of Show Business. Viking.
} 
(Salganik et al. 2020) $)^{5}$. Yet, such evidence doesn't appear to dampen the general faith in our 'datafied' future.

It is important to recognize, therefore, that 'data science' - the field of expertise that has come to define the digital in our times - has never really been a 'disenchantment'. It has relied, unquestionably, on the warm fuzziness of human fascination and allure, just as much as on the cold, hard, and irrefutable domain of 'facts'. However, the point here is certainly not to dismiss any ideological notion of 'dataism' - 'a widespread belief in the objective quantification and potential tracking of all kinds of human behavior and sociality' (van Dijck 2014: 198) (emphasis in original). Following Dourish and Bell (2011), the point is to recognize that anything 'mythical' about the digital is not simply false or erroneous but rather is indicative of what animates and gives shape to our contemporary 'datafied' society. For example, we need to acknowledge and take seriously the idea that our lives are infused with data, not simply because technological progress is 'inevitable' (by virtue of the fact that technologies are so unquestionably 'good' at what they do). Rather we need to see our condition as the result, both of society's collective trust in the idea that producing data for corporations and government will be beneficial, and upon a long-standing devotion to the notion of solving societal problems with a 'technical fix' (Robins and Webster 1989).

\section{Postdigital Conundrums of Technology and Religion (Maggi Savin-Baden)}

As we live through the complexity of the management (or not) of a global pandemic, full of mixed messages, many of us are reflecting on mortality. Faith, mortality, and death are themes in T.S. Eliot's The Wasteland (Eliot 1922) along with sorrow and compassion.

\section{Dayadhvam: I have heard the key \\ Turn in the door once and turn once only \\ We think of the key, each in his prison \\ Thinking of the key, each confirms a prison \\ Only at nightfall, aethereal rumours \\ Revive for a moment a broken Coriolanus}

Yet the poem, written in 1922 prompts us to question today how, if the world is getting smarter and more advanced, do we not know how to manage in the face of a virulent virus? How too then does our smart connected world deal with death? The meaning of the words by Eliot have resonance with our current situation, a sense of resignation (peace which passeth understanding). His words too seem to prompt us to consider an alternative set of values and recognize that we are, and will be living, in a culture and a value system new to us which may offer an alternative to our own dead world.

For most people, marking the end of life today increasingly includes memorials, whether at sites of roadside crashes or in online spaces. In a post-modern context of mixed religious beliefs and secular outlooks this affords a safe ritual space (Brock 2010: 64). Digital spaces are invisible seen as spaces of connection; yet as lock-down

\footnotetext{
${ }^{5}$ It should be noted that none of the techniques included in this study, including simple statistics, were able to make accurate predictions.
} 
occurs, we are indeed very much, as Eliot points out, in our own prisons, both physically and metaphorically. Further, as the death toll rises the shock and loss does too and as science fails us instead, we turn to digital memorialization as a means of sharing our locked-down, locked-in grief.

However, the ideas and practices associated with digital afterlife have moved beyond digital memorialization towards a desire to preserve oneself after death, illustrating disenchantment with religious provision but also confusion about just where people go after death. The result is that many people create social media mourning rituals such as 'speaking' to dead loved ones on Facebook, others are enchanted by the idea of creating a legacy or an avatar to leave behind. What seems particularly puzzling is that neither science nor religion has many answers about death. One of the central difficulties is that Christianity and other faiths find digital afterlife creation disconcertingly disembodied, and it is not clear whether it promotes particular views about bodily forms in the afterlife. People of faith I have interviewed recently have no real sense of what the afterlife might mean for them, but many ponder on conundrums such as the environmental footprint that is left behind by the data of the dead, as the bereaved do not delete the footprint of the dead and neither do services such as Facebook or Twitter.

There are concerns too about the lack of laws that govern the data of the dead, this digital legacy, and the lack of religious guidance on digital afterlife practices. Yet perhaps the real enchantment of the digital is its perpetuity - the photographs, the messages, the legacy: the afterlife; an afterlife that prevents us from being free to die also introduces questions about how 'the dead' might be classified.

\section{The God of Cats: Education for Re-enchantment with Science and Religion (Liz Jackson)}

The so-called separation of church and state comes with many costs. As mentioned, it reduces the history of social movements to the 'religious' and the 'secular', although no such divide has existed. At the same time, it obscures questions about the way people and societies operate today, as if people have rational brains separated from their affective, social, existential selves. Classes that aim to historicize and contextualize human experience in the past and present are in vogue today, to help remedies these myopic ways of thinking. Exploring the postdigital context allows for even more critically nuanced approaches to human existence, by opening another door to how science and technology do not exist without human affect, fantasy, and enchantment.

A case in point is the human relationship with cats. It was appreciated, before the digital and postdigital ages, that humans had spiritual relationships with cats. In ancient Egypt, they were associated with the goddesses Isis and Bastet-Artemis in ancient Greece. Cats have been associated with good fortune in Japan, now popularized in Maneki Neko figures adorning shop windows in many Asian countries today. People tend to think of this history as antiquated, as if relationships of humans with cats have become more rational. A postdigital approach complicates this picture.

The postdigital condition is marked not primarily by being 'after' the digital age, but further by 'dragging digitalization and the digital — kicking and screaming - down from its discursive celestial, ethereal home and into the mud' (Jandrić et al. 2019; Arndt et al. 2019). In this context, an examination of the postdigital age reveals that it shares with 
the predigital human fascination with cats. A nuanced exploration of the ancients would invite skepticism regarding simplistic conclusions about the past: Did the ancients really worship cats? Perhaps they simply liked to represent them. Similar inquiries can be made today. Jason Eppink's exhibit 'How Cats Took Over the Internet' shows that love of cats in online memes and websites says more about humans than it does about cats (Smith 2015). Cats 'rule' the internet, as they ruled artistic and other mediated spaces in the past. Might we worship cats in the same irrational way our apparently more religious and spiritually inclined ancestors did?

Far from being banal, the case of cats exposes the postdigital age as hardly more intellectual and rational. That cats dominate online space invites reconsideration of commodity fetishism, the way media operates upon deep parts of ourselves that are prerational, non-rational, or irrational (Marx 1867; Myrick 2015). The example also reminds that enchantment and the spiritual are not only celestial but part of everyday worldly life, while the concept of pure secular rationality remains quite abstract from that same world.

\section{Postdigital Caravaggio: Science, Art, and Education (Nina Hood and Marek Tesar)}

Michelangelo Merisi (1571-1610), commonly known as Caravaggio, perhaps seems as an odd place to begin this short piece. But the contradictions, challenges, and conflicting relationships present in both Caravaggio's art and his life provide a fascinating launching pad. Caravaggio can be described as an unorthodox artist, whose distinctive style and work with light and shadows, as well as his risque (for the time period) portrayal of non-religious subjects represented a break from traditional religious painting. Caravaggio was both a rebel artist and a rebel citizen. He resisted and pushed the boundaries and rules governing painting and art more generally, as well as those governing everyday life, as imposed primarily by the Church. For anyone who has encountered one of Caravaggio's paintings in situ, for example, in Santa Maria del Popolo in Rome or at St John's Co-Cathedral in Malta, they will know the sense of awe that overcame them, a sense of enchantment, which starts from his rebel subjectivities.

There is something powerful about the relationality between ontology and aesthetics, about the interconnections and relationships among religion, art, and science. While on the surface seemingly oxymoronic, in the history of Western thought, they blend together in ever changing and ever questioning combinations. During his life, Caravaggio often was portrayed as an outsider, a challenger of orthodoxy, but at the same time balancing controversy and the pushing of boundaries with convention and tradition. Similarly, through history, scientists and the science they developed have similarly found themselves in this challenging and outsider space. Linking art, scientific discovery, and religion is the sense of enchantment, of wonder, as well as disenchantment and a corresponding questioning and at times unresolved wondering invoked across all three.

However, overtime, there is no doubt that science has redefined our ontologies of ourselves in relation to our lives and education (see Jandrić et al. 2019); while at the same time art and aesthetics, and axiology, have managed to keep their distinctive subjectivities. While techno art or bio-art are a current new normality, conducting an exploration of the ontology of contemporary art and linking it with Caravaggio, who enacted a shift towards a cutting-edge science of art and in doing so initiated a redefining of the art form (like so many artists before him and after him also did), demonstrates the origin of such connections in the seventeenth century. The tension 
between Caravaggio's subjectivity and the religious world is ever manifest in his work. From sublime to the aesthetics, this liminal space pushes enchantment with the world. Just like the child being enchanted with a device; with a painting; with a newly learnt word. In the postdigital realities this does not come as a tension but as a progression; not as a cacophony but as something powerful and enchanting (see Hood and Tesar 2019; Tesar and Hood 2019). Just like with the child, this new logic of science and art has also made it necessary for artists to get acquainted with new epistemologies and a new logic of producing reality within the techno-scientific regime.

\section{Conclusion (John Reader and Petar Jandrić)}

Our question about the enchantment, disenchantment, re-enchantment continuum elicited a wide and creative range of responses. A theme to emerge is that of continuities and discontinuities. Each term brings its own ambiguities and questions. Is that which we see as enchanted any more than a distorted form of human activity or does it contain ideas which are still of value? Is that which is supposedly disenchanted by science perhaps more enchanted in our postdigital reality than we care to imagine? Can any project of re-enchantment avoid the challenge of both returning to the past, such as indigenous cultures, and projecting into an unknown future, such as transhumanism?

Wherever any of us might place ourselves along this spectrum, there is the task of working out the social, intellectual, and political implications of where we stand. If a shared concern is that of transforming a world in which forms of reductionism endanger life, both human and non-human, then the stance that we adopt needs to possess the capacity to inform and shape practice as well as belief. As we ponder about philosophical and theological questions, we should never forget about inequalities and especially those who have been historically and presently oppressed by our theories and practices. Our epistemologies, and our ontologies, can never be divorced from our political economies.

There may be no straightforward or linear process that can be categorized as reenchantment as we need to take into account both the continuities and discontinuities. The demarcation lines and boundaries that we draw between religion, science, and politics are themselves cultural and intellectual constructs and thus porous, fluid, and always open to question and revision. To this list, we should definitely add other important forms of human engagement with the world such as the arts. Ontological and epistemical differences, and their apparent incommensurability, should not prevent us from continuous engagement in various forms of (postdigital) dialogue (Jandrić 2017; Jandrić et al. 2019).

Extent, depth, and above all diversity of contributions to this article, indicate a strong need for such conversations and interactions across disciplinary perspectives, religions, and political positions. This collective exploration the enchantment, disenchantment, re-enchantment continuum indicates that various knowledge and belief systems have much more in common than our disciplinary approaches tend to represent: data theorists, and theologists, exhibit very similar levels of enchantment with the world. So where do the mythical, mystical, and spiritual end and the rational, objective, and empirical begin? How do we find our bearings in the midst of this complexity and 
where do we search for resources that are trustworthy and reliable? Perhaps a new civil science alongside a new civil religion might contribute to a renewed public life for the postdigital age and guide us as we explore the possibilities of a post- or transhumanism? Both would require that we continue the conversations and deepen the interactions, both human and more than human.

\section{Open Review 1: Do We Really Want a 'Reenchanted' World? Be Careful What You Wish For (Steve Fuller)}

We have been long accustomed to thinking about 'science' as a 'Western construct'. At first, this was to the credit of Europe, as when Joseph Needham (1954) tried to explain in the mid-twentieth century why the 'Scientific Revolution' took place there three centuries earlier rather than in the more advanced civilization of China. Nowadays, of course, 'Eurocentrism' carries an entire spectrum of negative connotations ranging from parochialism to imperialism. What is perhaps not so obvious is that 'religion' is equally a Western construct. This point is key to understanding the spirit in which Max Weber (1963) introduced the 'enchantment/disenchantment' binary, which roughly corresponds to 'religious/secular'. Thus, those who speak today about a possible 'reenchantment' of the world usually identify with a 'post-secular' mentality.

It is frequently observed that religions - perhaps especially the great 'world religions' - share little in terms of common doctrine, even with regard to such fundamental matters as the existence of God. This does not deny the filial relations among the Abrahamic religions, and that at least to Western eyes, Buddhism look like a Protestantstyle revolt against Hinduism (e.g. Bergson 1977). But those who have gone the extra mile with Karl Jaspers (1953) in trying to comprehend the rise of the world religions in one 'axial age' of global spirituality appear on closer inspection to be engaged in wishful acts of 'synchronicity'. Nevertheless, the emergence of 'religion' as an analytic category - typically in the context of 'comparative religions' - in the mid-nineteenth century has a clear source. A 'religion' in this sense is simply a residual category for all pre-modern modes of complex social organization.

This explains the prominence of the 'world religions' to the study of religion (Masuzawa 2005). They are the most direct competitors, in terms of both scale and scope, to what modern nation-states aspire to deliver. Moreover, these religions have attempted to achieve these ends by means radically different from those used by the 'moderns' studying them. Consider the problem of 'social order', which looms large in modern sociology. In many world religions, matters of 'faith', understood as a certain receptive disposition to the world, can solve the problem in ways that have required coercion and even the threat of violence — or the 'monopoly of force', as Weber defined the state - in the modern period to achieve comparable results. Patterns of behaviour that now require explicit formulation ('enacted into law') from a contrived ('socially contracted') central authority had previously enjoyed a 'natural' intergenerational passage through the family as mores and customs.

Of course, this is no more than a stereotype of the world religions; let alone all religions. Nevertheless, it is the conception of religion that fascinated Weber and other modern sociologists. For some of Weber's contemporaries, this fascination carried a tinge of nostalgia for 'the world we lost'. However, Weber remained a modernist who accepted 'disenchantment' as the price we have paid for living in a world in which we 
know enough about its inner workings that we can turn them to our advantage - and take responsibility for the consequences. Here Weber's German is telling: Entzauberung is his word for 'disenchantment', which implies a loss of magic, the breaking of a spell.

This helps to explain the centrality of theodicy to Weber's sociology of religion. In the Abrahamic tradition, starting with the Book of Job, it has referred to God's sense of justice, specifically the deity's tolerance of evil in the world. However, Weber broadened the concept to cover the meaning of life itself - and here he detected a pattern across all the world religions. In the 'enchanted' world, the meaning of life is ultimately hidden in, say, the mind of God or the outworking of fate. Thus, theology is preoccupied with guessing the 'reason why' things happen as they do-very much in the spirit of trying to guess how magic works. Eventually 'magicians' emerge who claim to know the answers. Frequently they were portrayed as arrogant charlatans, pretending to know things that no one could ever know. However, the privileging of humanity in the Abrahamic religions encouraged a second look. And the more that the magicians' claims were tested, the more it became possible both to explain and manufacture effects that were previously seen as beyond human comprehension and control. Modern science and technology are the legacy of this 'disenchanted' world.

Disenchantment involves humanity switching roles from spectator to conjurer of magic. It is a familiar trope from Existentialist theology, where it carries a heavy dose of irony. God looks glorious from afar and we desire to be one with Him. But upon arrival, we come to realize that we had been suffering from an optical illusion. This applies not only to pious traditional believers but also to the impious 'transhumanists' who at least since Ludwig Feuerbach have talked explicitly of a secular apotheosis (Fuller and Lipinska 2014: chap. 2). In the one case, 'God' turns out to be an empty signifier; in the other, it poses an impossible burden of responsibility over matters of life and death. But neither involves 'redemption' or 'salvation' in any obvious sense. The early 1960s US television series, The Twilight Zone was all about 'disenchantment' in this sense, the subtext of which is 'Be careful what you wish for'.

With all this in mind, is a return to 'enchantment' possible, let alone desirable? In the spirit of Postdigital Science and Education, let me propose that, for better or worse, a 're-enchantment' had already begun within a decade of Weber's declaration of 'disenchantment' and has continued apace for the past century. The vehicle of reenchantment has been modern technology itself, especially as it has become increasingly consumer-facing, 'black boxed' and 'user-friendly'. The society that Aldous Huxley satirized in 1932 in Brave New World was founded as a cult surrounding Henry Ford, in which the grill from the front of an old Model $\mathrm{T}$ functions as a holy relic. Fast forward to the current century, we find billions of people deeply dependent on smartphones and social media, only a fraction of whom have the vaguest idea of how they work. In this context, McKenzie Wark's (2004) early call for a 'hacker' class consciousness and Douglas Rushkoff's (2010) pointed cri de coeur, 'Program or Be Programmed!', may come to read in retrospect as the starting shots in a new and salutary wave of disenchantment. But for this to happen, we need to realize that we have been long reenchanted by technology, and much of the recent 'post-secular' turn has been about ideology catching up with the material conditions of our existence. 


\section{Open Review 2: At The Heart Of It All Is Trust... (Chris Baker)}

The challenge of how to renew and sustain civic life within the context of a postdigital public sphere is a challenge highlighted by this fascinating collection. In short, this challenge relies on reproducing and sustaining social and political trust. In an era of fake news and the lurch to tribal populism, this challenge was extraordinarily complex already. It now takes on even greater political and ethical urgency in the new and as yet uncharted space of a post Covid-19 society. For me the focus of this challenge is located in the rush to develop a 'track and trace' app as part of the post lockdown response, and the near certainty of knowing that 'emergency' social measures policed by the use of digital technology will quickly become permanent features shaping the way we live.

In the UK, the option has been to go for a home-grown app developed by the digital development arm for the National Health Service (NHSX), which will transfer contact tracer data to centralized British Government / National Health Service servers. Most other governments have opted for the decentralized app developed by Google and Apple which will hold our data on their disparate private servers. The bottom line seems to be 'Who do you trust most to respect your privacy and the freedom that comes with it. The state or private corporations?' The answer will probably be neither, but then we seem to have already moved to a cultural payoff moment where we sacrifice our right to privacy for the right to access limitless information and new forms of digital 'enchantment' for our own consumption.

More disturbing still, however, is evidence from societies like China that have already developed their contact tracing apps into immunity-style digital 'certificates'. These can be shown on smart phones and allow you access to goods and services in the public space. A red (as opposed to green) colour of your app certificate, generated by algorithms over which you have no knowledge or control could become a gateway to a permanent exclusion and underclass - where let's face it - the elderly, minority communities, the poor, the disabled, political dissidents etc. will be corralled. They will be quarantined and stigmatized in such ways as to ensure that their quality of life and freedom of mobility will conspicuously constrained and inferior. In other words, it could be business as usual, but much worse, and now depoliticized under the mantra of preserving communal health and safety.

So how might we respond to the challenge to sustain civil religion, civil science and civil society, all of which rely on relationships of trust? The Irish philosopher of religion, Richard Kearney, defines the current era as 'anatheistic'. In the context of the West, he suggests that we have moved from theism (the belief in an 'Omni-God of sovereignty and theodicy' to the death of God (i.e. atheism) into a new liminal space of anatheism 'the option of a God still to come - or a God still to come back again ... a supplementary move of aftering and overing' (Kearney and Zimmermann 2016: 17). He identifies three cultural shifts that epitomize the current anatheistic Zeitgeist; namely, a new appreciation of the Sacramentality of the Material; a renewed interplay between Religion and the Imagination; and what he defines as The Transformative Call of the Stranger.

This category is perhaps the one that best reflects the concerns of this volume. It encapsulates the call of the divine to engagement and participation through our response to the Other, whose demands either provoke a retreat into the familiar, or a foray into a new, more risky, but ultimately more satisfying future - what Kearney calls 
a form of annunciation. It can often come in the guise of a 'cry in the street', i.e. an unexpected irruption into our lives by an Other that opens up new lines of flight in the assemblages of both our individual lives and the localities in which we live.

The anatheistic phase thus reflects for Kearney an era of sublimated longing for reconnection and re-enchantment that the postdigital age now mediates so ubiquitously for us and either distorts and weakens, or potentially enhances. For the sake of a viable public sphere populated by civil religion, civil society and civil science we need, across disciplines and ideologies, to locate, analyze and promote the latent potential of the digital to mediate physical bonds of connection and trust. Only in this way can we build up immunity against a de-politicized, spoon-fed, capitalistic, and bio-powered future being conjured up for us_-right now!

\section{References}

Alesse, L. (2020). With constitutional questions murky, some churches continue to defy restrictions on gatherings. ABC News, 5 April. https://abcnews.go.com/Health/constitutional-questions-murky-churches-continue-defyrestrictions-gatherings/story?id=69973339 https://abcnews.go.com/Health/constitutional-questions-murkychurches-continue-defy-restrictions-gatherings/story?id=69973339. Accessed 6 April 2020.

Aranga, M., Mika, C., \& Mlcek, S. (2008). Kia Hiwa Ra! Being watchful: The challenges of student support at Te Whare Wānanga o Awanuiārangi. MAI Review, 1(6), 1-12.

Arndt, S, Asher, G., Knox, J., Ford, D., Hayes, S., Lazaroiu, G., Jackson, L., Mañero Contreras, J., Buchanan, R., D'Olimpio, L., Smith, M., Suoranta, J., Pyyhtinen, O., Ryberg, T., Davidsen, J., Steketee, A., Mihăilă, R., Stewart, G., Dawson, M., Peters, M. (2019). Between the blabbering noise of individuals or the silent dialogue of many: a collective response to 'Postdigital science and education'. Postdigital Science and Education, 1(2), 446-474. https://doi.org/10.1007/s42438-019-00037-y.

Baldwin, J. (1998). James Baldwin: Collected essays. New York: Library of America.

Bergson, H. (1932/1977). The Two Sources of Morality and Religion. South Bend, IN: Notre Dame University Press.

Borges, J., \& Weinberger, E. (1999). Selected Non-Fictions. New York: Penguin.

Boyd, D., \& Crawford, K. (2012). Critical questions for big data. Provocations for a cultural, technological, and scholarly phenomenon. Information, Communication \& Society, 15(5), 662-679. https://doi. org/10.1080/1369118X.2012.678878.

Brock, B. (2010). Christian Ethics in a Technological Age. Grand Rapids, MI: William B. Eerdmans Publishing Company.

Caputo, J. D. (2013). The Insistence of God: A Theology of Perhaps. Bloomington, IN: Indiana University Press.

Deloria Jnr, V. (2001). American Indian metaphysics. In V. Deloria Jnr \& D. Wildcat (Eds.), Power and place: Indian education in America (pp. 1-6). Golden, CO: Fulcrum Resources.

Devlin, H., \& Boseley, S. (2020). Scientists criticise UK government's 'following the science' claim. The Guardian, 23 April. https://www.theguardian.com/world/2020/apr/23/scientists-criticise-uk-governmentover-following-the-science. Accessed 6 April 2020.

Diseko, L. (2020). Is coronavirus coming between people and their faith? BBC News, 10 March. https://www. bbc.com/news/world-51819117. Accessed 6 April 2020.

Dourish, P., \& Bell, G. (2011). Divining a Digital Future: Mess and Mythology in Ubiquitous Computing. Cambridge, MA: MIT Press.

Eliot, T. S. (1922). The Wasteland. New York: Boni and Liveright.

Fanon, F. (1952). Black Skin, White Masks. New York: Grove Press.

Freire, P. (2011). The banking concept of education. In E. Hilty (Ed.), Thinking About Schools. Boulder, CO: Westview Press.

Fuller, S., \& Jandrić, P. (2019). The Postdigital Human: Making the history of the future. Postdigital Science and Education, 1(1), 190-217. https://doi.org/10.1007/s42438-018-0003-x.

Fuller, S., \& Lipinska, V. (2014). The Proactionary Imperative. London: Palgrave Macmillan.

Goodyear, P., \& Ellis, R. A. (2008). University students' approaches to learning: Rethinking the place of technology. Distance Education, 29(2), 141-152. https://doi.org/10.1080/01587910802154947. 
Hanson, H.Y. (2017). Address by Shaykh Hamza Yusuf. https:/www.templetonprize.org/laureatesub/plantinga-address-by-shaykh-hamza-yusuf/. Accessed 6 April 2020.

Heidegger, M. (1967). What is a Thing? South Bend, IN: Gateway Editions.

Heidegger, M. (1977). The question concerning technology and other essays. Trans. W. Lovitt. New York: Garland.

Hejnol, A. (2017). Ladders, Trees, Complexity, and Other Metaphors in Evolutionary Thinking. In A. Tsing, H. Swanson, E. Gan, \& N. Bubandt (Eds.), Arts of Living on a Damaged Planet: Ghosts of the Anthropocene (pp. G87-G102). Minneapolis, MN: University of Minnesota Press.

Himanen, L., Geurts, A., Foster, A. S., \& Ronke, P. (2019). Data-driven materials science: Status, challenges, and perspectives. Advanced Science, 6(1), 1900808. https://doi.org/10.1002/advs.201900808.

Hood, N., \& Tesar, M. (2019). Postdigital childhoods in the time of anthropocene. Postdigital Science in Education, 1(2), 307-310. https://doi.org/10.1007/s42438-019-00062-x.

Hudis, P. (2005). Marx's critical appropriation and transcendence of Hegel's Theory of Alienation. Presentation to Chicago Local of News and Letters Committees, November 21.

Jandrić, P. (2017). Learning in the Age of Digital Reason. Rotterdam: Sense.

Jandrić, P., Knox, J., Besley, T., Ryberg, T., Suoranta, J., \& Hayes, S. (2018). Postdigital Science and Education. Educational Philosophy and Theory, 50(10), 893-899. https://doi.org/10.1080 /00131857.2018.1454000.

Jandrić, P., Ryberg, T., Knox, J., Lacković, N., Hayes, S., Suoranta, J., Smith, M., Steketee, A., Peters, M. A., McLaren, P., Ford, D. R., Asher, G., McGregor, C., Stewart, G., Williamson, B., \& Gibbons, A. (2019). Postdigital dialogue. Postdigital Science and Education, 1(1), 163-189. https://doi.org/10.1007/s42438018-0011-x.

Jaspers, K. (1953). The Origin and Goal of History. London: Routledge \& Kegan Paul.

Kearney, R., \& Zimmermann, J. (2016). Reimaging the Sacred. New York: Columbia University Press.

Keller, C. (2015). The Cloud of the Im-possible: Negative Theology and Planetary Entanglement. New York: Columbia University Press.

Kline, M. (1982). Mathematics, the Loss of Certainty. Oxford: Oxford University Press.

Marx, K. (1867). Das Kapital. Capital: Volume 1: A critique of political economy. London: Penguin.

Masuzawa, T. (2005). The Invention of World Religions. Chicago: University of Chicago Press.

McLaren, P. (2015). Pedagogy of Insurrection: From Resurrection to Revolution. New York: Peter Lang.

Mika, C. (2017). Indigenous education and the metaphysics of presence: A worlded philosophy. Oxon: Routledge.

Mika, C., \& Stewart, G. (2015). Māori in the kingdom of the Gaze: Subjects or critics? Educational Philosophy and Theory, 48(3), 300-312. https://doi.org/10.1080/00131857.2015.1013017.

Myrick, J. G. (2015). Emotion regulation, procrastination, and watching cat videos online: Who watches Internet cats, why, and to what effect? Computers in Human Behavior, 52, 168-176. https://doi. org/10.1016/j.chb.2015.06.001.

Needham, J. (1954). Science and Civilization in China. Cambridge, UK: Cambridge University Press.

OECD (2015). Data-Driven Innovation Big Data for Growth and Well-Being, https://www.oecd. org/sti/ieconomy/data-driven-innovation.htm. Accessed 4 May 2020.

Owaisi, F. A. (1999). Manaqib Imam Azam. (Arabic original by Mawfiq bin Ahmad Makki). Lahore: Maktabah Nabaviyyah.

Palmer, K. D. (2012). Seeking to Understand the Western Worldview - Introduction to the Study of the Deep Structure of the Western Worldview. Unpublished essay.

Peters, M. A. (2019). Lotus heaven. Educational Philosophy and Theory. https://doi.org/10.1080 /00131857.2019.1693243.

Peters, M. A., \& Besley, T. (2019). Critical philosophy of the postdigital. Postdigital Science and Education, 1,(1) 29-42. https://doi.org/10.1007/s42438-018-0004-9.

Peters, M.A. (2017). Algorithmic Capitalism In The Epoch Of Digital Reason, http://www.uta. edu/huma/agger/fastcapitalism/14_1/Peters-Algorithmic-Capitalism-Epoch.htm. Accessed 4 May 2020.

Pettman, D. (2016). Infinite distraction: Paying attention to social media. Cambridge, UK: Polity Press.

Pew Research Center (2020). Iranians' Views Mixed On Political Role For Religious Figures. https://www. pewforum.org/2013/06/11/iranians-views-mixed-on-political-role-for-religious-figures/. Accessed 4 May 2020.

Reader, J., \& Evans, A. (2019). Ethics after new materialism: A modest undertaking. Rochdale: William Temple Foundation. https://williamtemplefoundation.org.uk/temple-ethical-futures/. Accessed 4 May 2020 .

Robins, K., \& Webster, F. (1989). The technical fix: Education, computers and industry. New York: Macmillan Education. 
Roth, A., Walker, S., \& Phillips, D. (2020). Churchgoers all over world come to terms with physical distancing advice. The Guardian, (30 March). https://www.theguardian.com/world/2020/mar/29/churchgoers-around-the-world-ignore-social-distance-advice. Accessed 4 May 2020.

Rushkoff, D. (2010). Program or Be Programmed. New York: OR Books.

Safarzadeh, N., \& Ahmadi, B. (2014). Barasi-ye tasvir-e fereshtegaan dar naghashi-ye dorey-e Qajar. Peykareh: Research in Visual Arts, 3(5), 47-56.

Salganik, M. J., Lundberg, I., Kindel, A. T., Ahearn, C. E., Al-Ghoneim, K., Almaatouq, A., et al. (2020). Measuring the predictability of life outcomes with a scientific mass collaboration. Proceedings of the National Academy of Sciences, 201915006. https://doi.org/10.1073/pnas.1915006117.

Schwab, K. (2017). The fourth industrial revolution. New York: Random House.

Smith, J. (2015). The tale of how cats clawed their way to internet stardom. The Wall Street Journal, 4 August. https:/www.wsj.com/articles/the-tale-of-how-cats-clawed-their-way-to-internet-stardom-1438736940. Accessed 6 April 2020.

Srnicek, N. (2017). Platform Capitalism. Cambridge: Polity Press.

Tesar, M., \& Hood, N. (2019). Policy in the time of Anthropocene: Children, childhoods and digital worlds. Policy Futures in Education, 17(2), 102-104. https://doi.org/10.1177\%2F1478210319831830.

Thandeka. (1999). Learning to Be White: Money, Race and God in America. New York: Continuum.

van Dijck, J. (2014). Datafication, dataism and dataveillance: Big data between scientific paradigm and ideology. Surveillance and Society, 12(2), 197-208. https://doi.org/10.24908/ss.v12i2.4776.

Walker, P., \& Morgan, D. (2011). Early Philosophical Shiism: The Isma'ili Neoplatonism Of Abu Ya'qub AlSijistani. Cambridge: Cambridge University Press.

Ward, K. (2018). Social networks, the 2016 US presidential election, and Kantian ethics: applying the categorical imperative to Cambridge Analytica's behavioral microtargeting. Journal of Media Ethics, 33(3), 133-148. https://doi.org/10.1080/23736992.2018.1477047.

Wark, M. (2004). A Hacker's Manifesto. Cambridge, MA: Harvard University Press.

Weber, M. (1963). The Sociology of Religion. Boston: Beacon Press.

Weber, M. (2004). The Vocation Lectures. Trans. R. Livingstone. Indianapolis and Cambridge: Hackett Publishing Company.

Weil, S. (1951). Waiting for God. New York: Harper.

Zuboff, S. (2019). The Age of Surveillance Capitalism: The fight for a human future at the new frontier of power. London: Profile Books.

\section{Affiliations}

John Reader ${ }^{1} \cdot$ Petar Jandrić ${ }^{2,3} \cdot$ Michael A. Peters ${ }^{4} \cdot$ Ronald Barnett $^{5} \cdot$ Marcin Garbowski $^{6}$. Veronika Lipińska ${ }^{7}$. Sharon Rider ${ }^{8} \cdot$ Ibrar Bhatt $^{9} \cdot$ Abdassamad $^{2}$ Clarke $^{10}$. Morteza Hashemi ${ }^{11}$. Andrew Bevan ${ }^{12}$. Eric Trozzo ${ }^{13}$. Alison

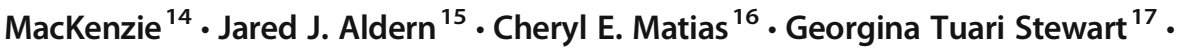
Carl Mika $^{18}$. Peter McLaren ${ }^{19,20}$. Tim Fawns ${ }^{11}$ • Jeremy Knox ${ }^{11}$ • Maggi Savin-Baden ${ }^{1}$ - Liz Jackson ${ }^{21}$ • Nina Hood ${ }^{22}$ - Marek Tesar ${ }^{22}$ - Steve Fuller $^{23}$. Chris Baker ${ }^{24}$

Petar Jandrić

pjandric@tvz.hr

John Reader

drjohnreader@hotmail.co.uk

Michael A. Peters

mpeters@bnu.edu.cn

Ronald Barnett

ron.barnett@ucl.ac.uk 
Marcin Garbowski

marcin.s.garbowski@gmail.com

Veronika Lipińska

veronika.lipinska@gmail.com

Sharon Rider

sharon.rider@filosofi.uu.se

Ibrar Bhatt

I.Bhatt@qub.ac.uk

Abdassamad Clarke

abdassamad@icloud.com

Morteza Hashemi

Morteza.Hashemi@ed.ac.uk

Andrew Bevan

andrewbevan@me.com

Eric Trozzo

ejtrozzo@gmail.com

Alison MacKenzie

A.Mackenzie@qub.ac.uk

Jared J. Aldern

JARED.ALDERN@UCDENVER.EDU

Cheryl E. Matias

cheryl.matias@uky.edu

Georgina Tuari Stewart

georgina.stewart@aut.ac.nz

Carl Mika

carl.mika@waikato.ac.nz

Peter McLaren

peter.mclaren1@gmail.com

Tim Fawns

tfawns@ed.ac.uk

Jeremy Knox

jeremy.knox@ed.ac.uk

Maggi Savin-Baden

m.savinbaden@worc.ac.uk

Liz Jackson

lizjackson@hku.hk

Nina Hood

n.hood@auckland.ac.nz

Marek Tesar

m.tesar@auckland.ac.nz

Steve Fuller

s.w.fuller@warwick.ac.uk 
Chris Baker

c.baker@gold.ac.uk

1 University of Worcester, Worcester, UK

2 Zagreb University of Applied Sciences, Zagreb, Croatia

3 University of Wolverhampton, Wolverhampton, UK

4 Beijing Normal University, Beijing, China

5 University College London, Institute of Education, London, UK

6 The John Paul II Catholic University of Lublin, Lublin, Poland

7 Independent Scholar, London, UK

8 Department of Philosophy, Uppsala University, Uppsala, Sweden

9 Queen's University, Belfast, UK

10 Independent Scholar, Nakskov, Denmark

11 University of Edinburgh, Edinburgh, UK

12 Independent Scholar, Oxford, UK

13 Australian Lutheran College, University of Divinity, Adelaide, Australia

14 Queen's University, Belfast, UK

15 School of Education and Human Development, University of Colorado, Denver, CO, USA

16 Interdisciplinary Research Institute for the Study in (In)Equality, University of Denver, Denver, $\mathrm{CO}$, USA

17 Auckland University of Technology, Auckland, New Zealand

18 University of Waikato, Hamilton, New Zealand

19 Northeast Normal University, Changchun, China

20 Chapman University, Orange, CA, USA

21 University of Hong Kong, Hong Kong, China

22 The University of Auckland, Auckland, New Zealand

23 University of Warwick, Coventry, UK

24 Goldsmiths, University of London, London, UK 